Research perspective

\title{
Differentiation of human dendritic cell subsets for immune tolerance induction
}

\section{Différenciation de cellules dendritiques humaines pour l'induction de la tolérance immune}

\author{
N. Deluce-Kakwata-nkor ${ }^{a}$, L. Lamendour ${ }^{a}$, V. Chabot ${ }^{b}$, A. Héraud ${ }^{a}$, Z. Ivanovic ${ }^{c}$, F. Halary ${ }^{d, e}$, \\ F. Dehaut ${ }^{b}$, F. Velge-Roussel ${ }^{\mathrm{a}, \mathrm{f}, *}$ \\ ${ }^{a}$ EA 4245 cellules dendritiques, immuno-modulation et greffes, université François-Rabelais de Tours, UFR de médecine, 10, boulevard Tonnellé, 37032 Tours \\ cedex, France \\ ${ }^{\mathrm{b}}$ Service recherche du laboratoire d'histocompatibilité et d'immunogénétique, établissement français du sang Centre-Atlantique, 2, boulevard Tonnellé, BP 40661, \\ 37206 Tours cedex 3, France \\ ${ }^{c}$ EFS Aquitaine-Limousin, place Amélie-Raba-Léon, CS 21010, 33075 Bordeaux, France \\ ${ }^{\mathrm{d}}$ UMR 1064, Inserm, centre de recherche en transplantation et immunologie (CRTI), université de Nantes, Nantes, France \\ e Institut de transplantation urologie néphrologie (ITUN), Hôtel-Dieu, CHU de Nantes, 30, boulevard Jean-Monnet, 44093 Nantes cedex 01 , France \\ ${ }^{\mathrm{f}}$ UFR des sciences pharmaceutiques, avenue Monge, 37000 Tours, France
}

\begin{abstract}
Objectives. - Since no further progress was achieved, in order to improve the long-term organ transplantation outcome, the immune tolerance appears as an interesting therapeutic goal. Dendritic cells (DCs) are specialized cells participating in the homeostasis of the immune response. Moreover, subsets of DCs, identified in humans, appear to have their respective competences in immune response modulation. Our objective is to purify from PBMC or to differentiate DC subsets from monocytes using several strategies and evaluate their IL10 secretion.

Methods. $-\mathrm{CD} 14^{+}$cells were purified from peripheral blood mononuclear cell (PBMC) by affinity beads and cultured with cytokines up to 7 days. The pDCs were purified with anti-BDCA-2 beads from PBMC fraction enriched by Percoll ${ }^{\circledR}$ gradient. The moDCs, pDCs and moLCs subsets were analyzed by phenotype labelling and FACS analyses and IL10 secretion measured by ELISA.

Results. - The moDCs were characterized by the CD209 expression and a lower expression of CD1a markers. Expression of CD207 and CD1a markers characterized moLCs and CD123 $/$ BDCA-2 ${ }^{+}$pDCs. Variable IL-10 secretions were shown between the three DC subsets, both at basal and activated levels.

Conclusions. - As the several DC populations studied have different capacities of IL-10 synthesis, they might play, among others, distinct roles in the induction of immune tolerance.
\end{abstract}

Keywords: Dendritic cells; DC subsets; Immuno-modulation; IL-10

\section{Résumé}

Objectifs. - L'induction de tolérance immune reste un challenge important dans le domaine de la transplantation d'organe. Les cellules dendritiques (DCs), piliers de la réponse immunitaire, jouent un rôle crucial aussi bien dans l'induction d'une immunité spécifique que dans celle d'une tolérance immune. Chez l'homme, il existe au moins quatre types de DCs effectrices majeures, les DCs conventionnelles (cDC), les DCs plasmacytoïdes (pDCs), les DCs inflammatoires (MoDCS) et les cellules de Langerhans (LCs). L'objectif du projet est de préparer différents sous-types de DCs (moDCs, pDCs, moLCs) afin d'analyser leurs capacités à synthétiser de l'IL-10.

\footnotetext{
* Corresponding author. EA 4245 cellules dendritiques, immuno-modulation et greffes, UFR de médecine, université François-Rabelais, 10, boulevard Tonnellé, 37032 Tours cedex, France.

E-mail address: velge@univ-tours.fr (F. Velge-Roussel).
} 
Méthodes. - La différenciation des moDCs et moLCs est faite à partir de monocytes CD14+ isolés des PBMCs, en présence de cytokines spécifiques. La purification des pDC est faite avec des billes anti-BDCA-2 à partir des PBMC.

Résultats. - Les moLCs différenciées sont caractérisées par l'expression de la Langerine (CD207) et de CD1a. Les moDCs se caractérisent par l'expression de CD209 et une plus faible expression de CD1a et les pDCs par l'expression conjointe de CD123 et BDCA-2. La synthèse d'IL10 est différente entre les trois sous-types de DCs étudiés au niveau basal comme activé.

Conclusions. - Les différentes populations de DC étudiées, parce qu'elles présentent des capacités variées, entre autres, pour la synthèse d'IL-10, pourraient jouer des rôles distincts dans l'induction de tolérance immune.

Mots clés : Cellules dendritiques ; Sous-types de DCs ; Immunomodulation ; IL-10

\section{Introduction}

Dendritic cells (DCs) are professional antigen-presenting cells that induce immunity upon detection of pathogens, while maintaining tolerance in response to innocuous molecules due to their functional plasticity [1,2]. Two main DC subsets, at last, have been identified in the blood, spleen, tonsil and lymph nodes including conventional DCs (cDCs), consisting of either BDCA1/CD1c ${ }^{+}$DCs or BDCA3/CD141 ${ }^{+}$DCs and plasmacytoid DCs (pDCs) consisting of $\mathrm{CD}^{2} 23^{+}$cells. cDCs are effective at antigen-specific stimulation of $\mathrm{CD}^{+}$and $\mathrm{CD} 8^{+} \mathrm{T}$ cells whereas pDCs specialize in producing type I interferons in response of virus motifs [3]. In the skin, three DC subsets have been described: Langerhans cells characterized by the expression of Langerin $\left(\mathrm{CD} 207^{+}\right)[4], \mathrm{CD} 1 \mathrm{a}^{+}$dermal DCs, and $\mathrm{CD} 14^{+}$dermal DCs, which all migrate into skin-draining lymph nodes [5]. Additional revised taxonomy of human blood DC subsets have been described based on Single-cell RNAseq including two subpopulations within BDCA1/CD1c ${ }^{+}$DCs $\left(\mathrm{CD} 1 \mathrm{C}^{+}-\mathrm{A}\right.$ and $\left.\mathrm{CD} 1 \mathrm{C}^{+}-\mathrm{B}\right)$ which are distinguished by their strong signature of inflammatory genes [6]. Moreover, a new DC subset "AS DCs" which share properties with pDCs have been identified in human blood, nevertheless, pDCs remains as "the natural interferon-producing cells" with weaker T cell proliferation induction ability [6]. Since their discovery, DCs have proved to play a central role in regulating immune responses. Tolerant DCs are often characterized by a low expression of surface MHC II molecules and co-stimulatory molecules (CD40, CD80 and CD86) and low T cell stimulatory ability [7]. Moreover, they usually show reduced IL-12 and increase IL-10. During the last decades, significant advances have been made in establishing methods to manipulate DCs in vitro to generate tolerant DCs [8] using cytokines such as: Il-10 alone [9] or in combination of transforming growth factor (TGFß1) [10]. Alternatively, pharmacological mediators including: 1,25-dihydroxyvitamin D3 [11], histone deacetylase inhibitors (HDAC) [12] or immunosuppressive drugs such as mycophenolate mofetil or rapamycin $[13,14]$ which modulate DCs in that sense. Despite the importance of Tol-DCs, the capacities of each DC subset to induce and promote immune tolerance remain unknown. We explore DC subset capacities of secreting IL-10 versus pro-inflammatory cytokines using PRRs agonist.

\section{Methods}

\subsection{Monocyte isolation and culture}

Cytapheresis products were obtained from Centre Atlantic Transfusion Department (EFS-CA). They were issued from the healthy adult volunteers who had given their written informed consent and the university ethic committee approved the procedure. Mononuclear cells were obtained from peripheral blood of healthy donors using Ficoll (Dutscher) density gradient centrifugation. The monocytes were then purified by a positive selection using CD14 microbeads (Miltenyi Biotec) (>90\% of purity). For immature monocyte-derived DCs (moDCs), monocytes were differentiated for 6 days in RPMI 1640 (Dutscher) medium supplemented with $10 \%$ FCS (Dutsher), $66 \mathrm{ng} / \mathrm{mL}$ granulocyte macrophage colony stimulating factor (GM-CSF, Miltenyi Biotec) and $25 \mathrm{ng}$ ng/mL IL-4 (Miltenyi Biotec). At day 6 , cells were collected and flow cytometry analysis was performed. For human moLCs, monocytes were cultured for 7 days in RPMI 1640 medium supplemented with the $2 \%$ human albumin (HAB, Vialebex LFB), $50 \mathrm{ng} / \mathrm{mL}$ GM-CSF (Miltenyi Biotec), and $10 \mathrm{ng} / \mathrm{mL}$ TGF-ß1 (Miltenyi Biotec), renewed at day 3. At day 7, cells were collected and FACS analysis was performed. The pDCs were isolated by negative selection using plasmacytoid dendritic cells isolation kit II (Miltenyi Biotec), from an enriched DC cells fraction, which was obtained by gradient centrifugation of PBMCs, Percol ${ }^{\circledR}$ (Healthcare) gradient centrifugation of PBMCs. Cells were gated based on their characteristic pattern of SSC and FSC. Doublets were excluded based on forward scatter height (FSC-H) and forward scatter width (FSC-W) and analysed for the double expression of CD123+ (IL$3 \mathrm{R}^{+}$) and CD303 (CLEC4 C, BDCA-2). The purity of population is up to $98,1 \%$.

\subsection{Flow cytometry analysis}

Cells $\left(1 \times 10^{5} / 100 \mu \mathrm{L}\right)$ were stained for $30 \mathrm{~min}$ at $4{ }^{\circ} \mathrm{C}$ with the following anti-human antibodies at the appropriate concentration or with the relevant isotypes: CD83-FITC (BD Biosciences), CD14-PE (Beckman coulter), CD86-PE (BD Biosciences), HLA-DR-APC (BD Biosciences), CD207APC (Biolegend), CD1A-AF488 (Biolegend), CD123-APC (Biolegend), BDCA-2-APC (Biolegend), CD209-PE (Beckman 
coulter). The cells were then washed with $1 \times$ PBS (Dutscher) and viable cells analysed on a Canto I flow cytometer (BD Biosciences). Results were expressed as the ratio of MFI (mean of fluorescence) of the marker on the MFI of the isotype control and referred as MFI ratio.

\section{ELISA}

MoDCs and monocyte-derived Langerhans-like cells (moLCs) $\left(1.10^{6} / \mathrm{mL}\right)$ were stimulated by lipopolysaccharides (LPS, TLR-4 ligand) $50 \mathrm{ng} / \mathrm{mL}$ (Invivogen), and $\mathrm{pDCs}$ by Classe A CpG-ODN 2236 (TLR-9 ligand), $1 \mu \mathrm{g} / \mathrm{mL}$ (Invivogen) for $48 \mathrm{~h}$ and then IL-10, IL12-p70 and IFN- $\alpha$ ELISA measurement was performed on culture supernatants of each DC subset according to the manufacturer instructions (eBiosience). Data were expressed as means \pm SD of 3 donors for $\mathrm{pDCs}$ and moDCs and as means of duplicate $\pm \mathrm{SD}$ of 1 donor for moLCs.

\subsection{Statistical analysis}

Histograms represent the mean values \pm S.D. Statistical significance was determined by the unpaired nonparametric Kruskal-Wallis test. Difference was considered significant when $P<0.05$.

\section{Results}

\subsection{Differentiation of DC subsets}

In order to obtain different DC subsets in sufficient quantities, we first explored the possibility of differentiating these DCs from monocytes using specific cytokine cocktail. Monocyte derived-cells were collected after a 6-day culture and identified using CD14, CD209, CD1a and CD207 as phenotypic markers. Cells differentiated in the presence of IL4 and GMCSF as moDCs expressed DC-SIGN (CD209) marker up to 93\% and among these, $40 \%$ are $\mathrm{CD}^{+} \mathrm{a}^{+}$(Fig. $1 \mathrm{~A}$ and $\mathrm{B}$ ). When cultured in the presence of GM-CSF and TGF- 31 , monocytes generated large number $(60 \%)$ of dendritic cells as moLCs that expressed Langerin (CD207) as referred to the literature [15] (Fig. 1A and B) but not CD209 compared to moDCs or CD14 and in minor levels compared to monocyte (Fig. 1A and 1B). The percentage of phenotypic markers, which were less than $5 \%$, has been considered as negative.

The pDCs were purified as described in methods (Fig. 1C). Cells were gated on the basis of double expression of CD123 and BDCA-2, pDCs characteristics markers. CD123+ BDCA$2^{+}$cells have been enriched $>4$-fold from $22 \%$ before separation to $>96 \%$ after negative column isolation (Fig. 1D).

For the pDCs purification, $1.10^{9}$ PBMC have been used to obtain $1.510^{6}$ of purified pDCs. Concerning the moLCs, $1.10^{7}$ monocytes have been used to obtain $6.10^{6}$ moLCs $(60 \%$ of $\mathrm{CD} 207^{+}$).

\subsection{Functional capacities of DC subsets}

The capacity to secrete IL-10 for each subset obtained has been evaluated by ELISA (Fig. 2A) after $48 \mathrm{~h}$ of stimulation using TLRs ligand such as LPS for moDC and moLCs and CPG-A ODN, (TLR-9 ligand) for pDCs. MoDCs IL-10 secretion increased between un-stimulated and LPS stimulated stage from $18.53 \pm 2.59 \mathrm{pg} / \mathrm{mL}$ to $204.91 \pm 22.14 \mathrm{pg} / \mathrm{mL}$. The immature pDCs have a basal secretion at $206.90 \pm 70.43 \mathrm{pg} / \mathrm{mL}$ and reduce their Il-10 secretion when stimulated with ODN at $125.07 \pm 23.24 \mathrm{pg} / \mathrm{m}$. We found out, as a preliminary result, that un-stimulated moLCs had neither, IL-10 basal secretion $(1.559 \pm 0.004 \mathrm{pg} / \mathrm{mL})$ nor with LPS stimulation. IL-12p70 secretion or interfon- $\alpha$ secretion as well as maturation marker have been evaluated after $48 \mathrm{~h}$ of stimulation by ELISA and flow cytometry respectively as control of responsiveness of each DC subsets due to stimulation. In presence of the pro-inflammatory stimulus, LPS or class A CPG-ODN, IL-12p70 or INF-alpha were secreted higher than non-stimulated DC (Fig. 2B) as well as the expression of maturation marker CD86, CD83 and HLA-DR (data not shown).

\section{Discussion}

As playing a key role on inducing immune response or immune tolerance, each DC subset might have different capacities of responsiveness due to PRRs stimulus. To study the capacity of each subset to induce immune tolerance, it is necessary to have a clear immuno-phenotypic definition of each DC population and the possibility to purify a sufficient amount of the phenotypically identified cells. The moDCs is a wellcharacterized model of DC differentiation and huge number of works published is related to this population $[8,16]$. It has also been used as therapeutic strategy in cancer for cell therapy [17] and in graft tolerance [18]. The plasmacytoid DCs are not easily derived from $\mathrm{CD}_{3} 4^{+}$progenitors but they could be purified from a PBMC fraction after an enrichment using a Percoll ${ }^{\circledR}$ gradient [19]. In humans, pDCs do not express the CD11c molecule, but strongly express the IL-3 receptor chain $\alpha$ (CD123). The identification of BDCA-2 markers, type C lectin and BDCA-4, the neuropilin-1 receptor, facilitated the identification of these cells in the blood [20]. The pDCs are the main source of virus-induced IFN- $\alpha$ in human peripheral blood. They migrate to different lymphoid tissues [3] and are found to be elevated in some tumours, in the skin of systemic lupus erythematous (SLE) patients and in the nasal mucosa of allergic patients [21]. pDCs play a central role in SLE pathogenesis through their unique ability to produce large amounts of type I interferon (IFN-I) upon TLR-7 or TLR-9 triggering [22]. The pDCs also promote immunological tolerance by inducing IL-10-secreting regulatory T cells (Treg). Indeed, after maturation, ICOS-L, which is overexpressed on pDCs, allows the development of IL-10 producing Treg lymphocytes, within Th1 or Th2 responses [9]. If many aspects of their properties remain to be study, pDCs are clearly involved in cancer and autoimmune subversion mechanisms and they express specific surface regulatory receptors involved in negative 
A
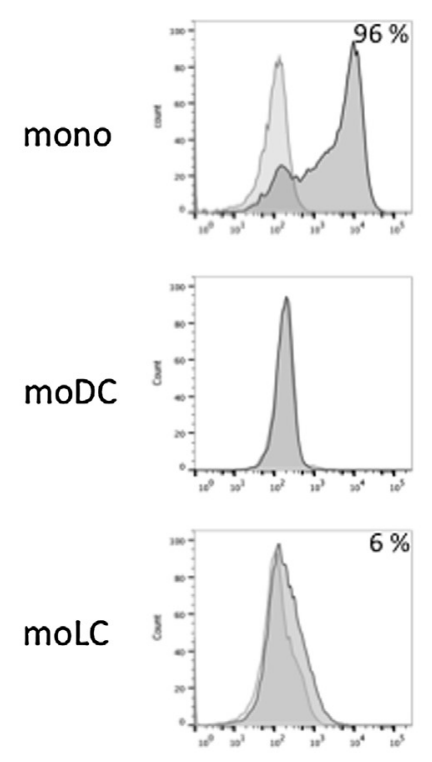

CD209
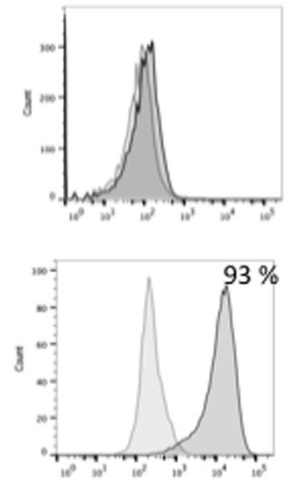

C

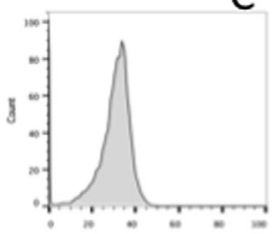

CD1a
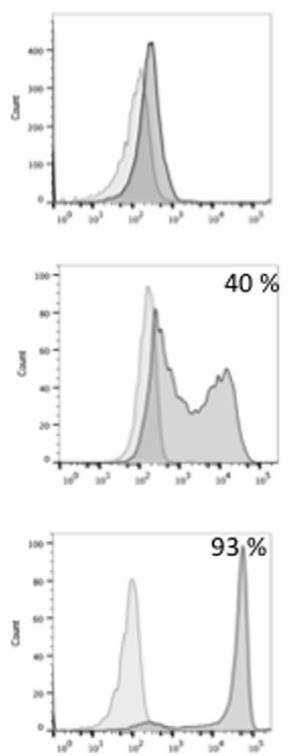

CD207
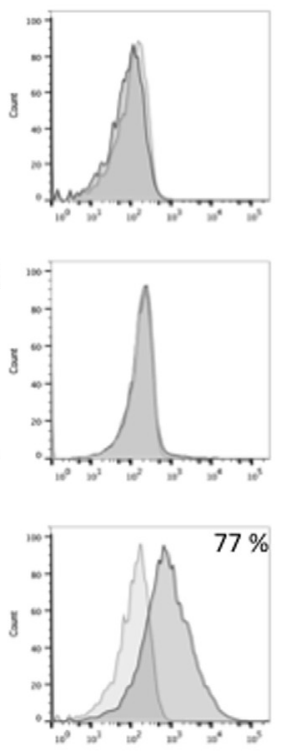

B

CD14

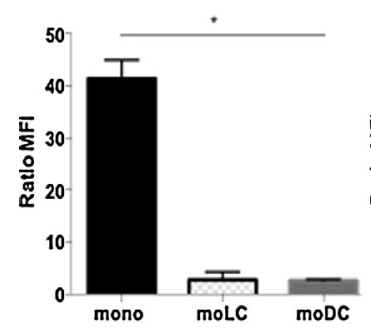

CD1a

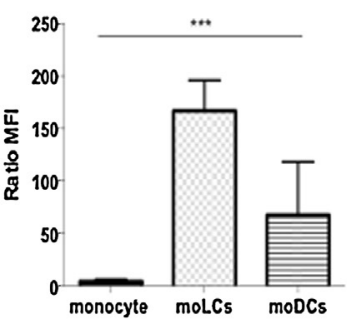

CD207

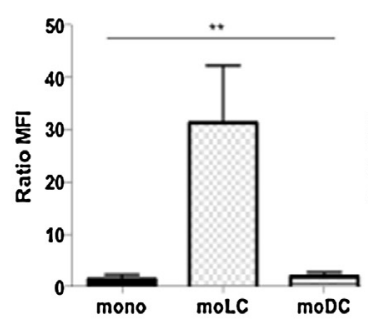

C
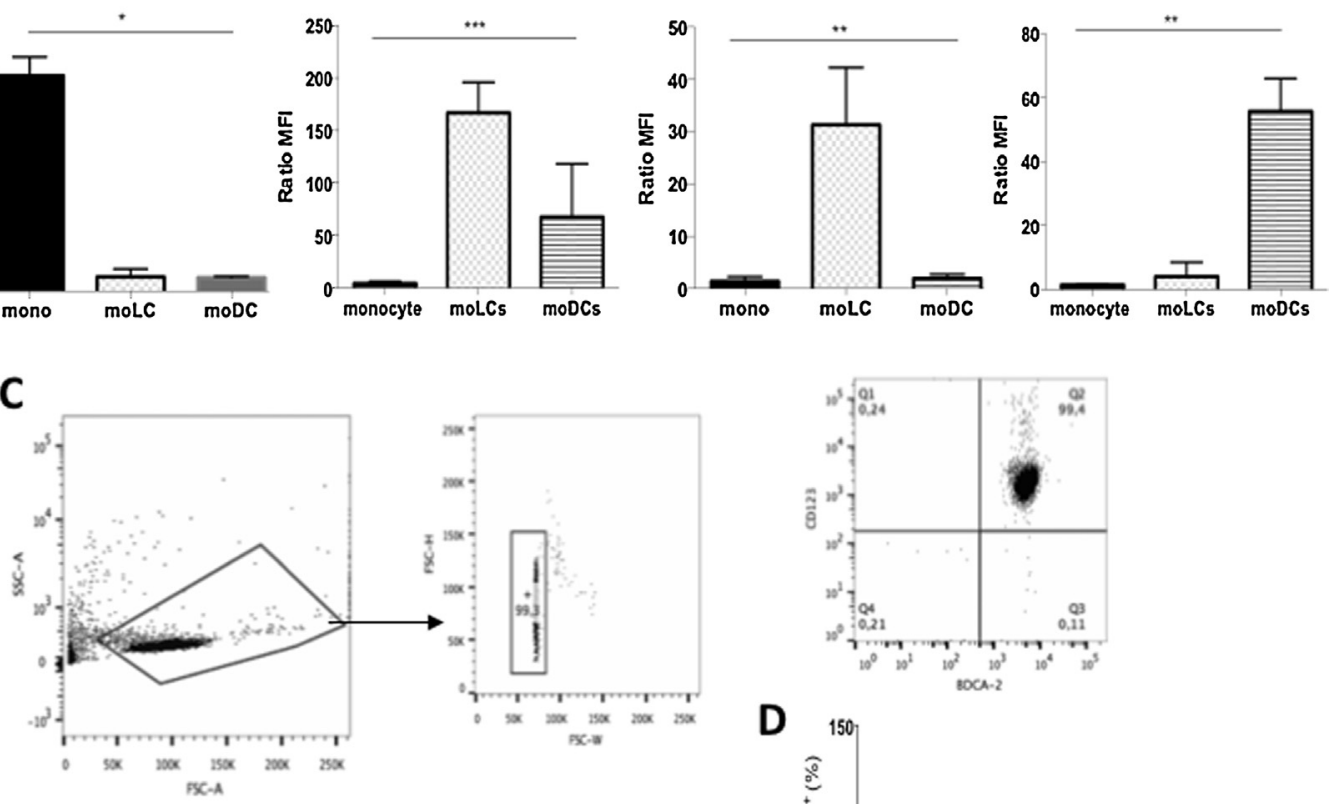

D

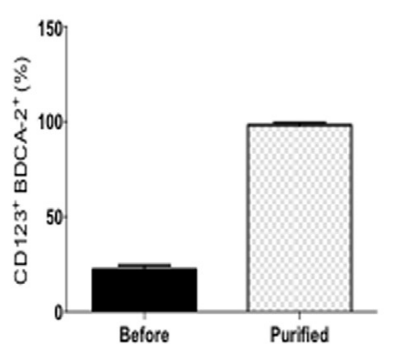

Fig. 1. Strategies for DC subset differentiation. MoLCs and moDCs subsets can be differentiated from monocyte in the GM-SCF and TGF-ß1 or GM-SCF and IL-4 respectively and they exhibit distinctive surface markers. A. A phenotypic analysis of moDCs and moLCs stained with a panel of antibodies specific to DC related surface markers. Flow cytometry result plots show isotype control (grey) and specific marker (black). B. MFI ratio of CD1a, Langerin (CD207), CD14 and DC-SIGN (CD209) expressions by flow cytometry displayed as ratio of MFI using MFI marker by MFI isotype control. These results are representative of 4 independent experiments $(n=4$; Kruskal-Wallis test; $* P<0.0145, * * P<0.005 ; * * * P<0.0006)$. C. pDCs were isolated using LD columns by negative selection from an enriched DC cells fraction. Cells were gated based on their characteristic pattern of SSC, and FSC. Doublets were excluded based on forward scatter height (FSC-H) and forward scatter width (FSC-W) (middle plot) and analysed for the double expression of CD123 and CD303 (BDCA-2). D. The percentage of CD123 ${ }^{+} / \mathrm{CD} 303^{+}$cells was evaluated before and after isolation $(n=3)$. 
A

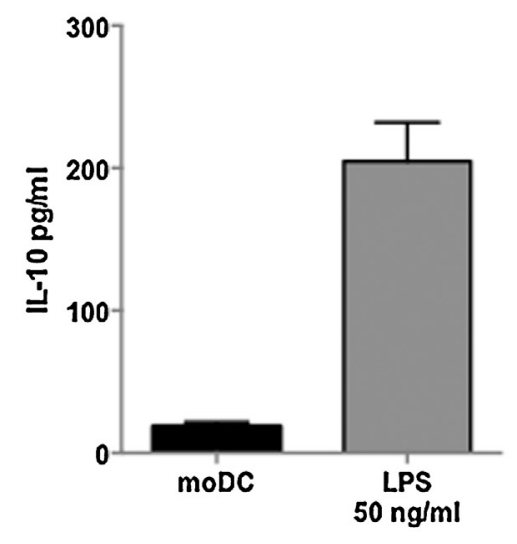

B

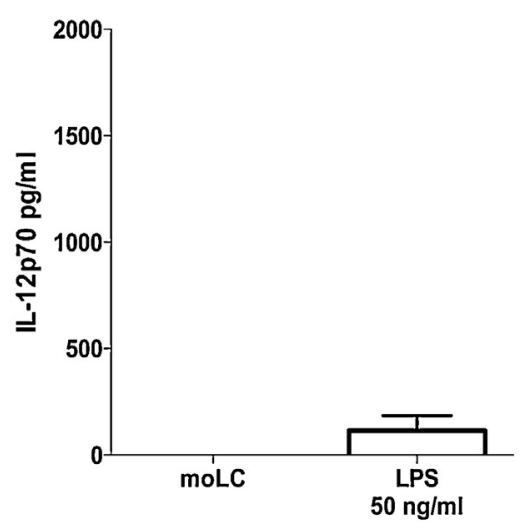

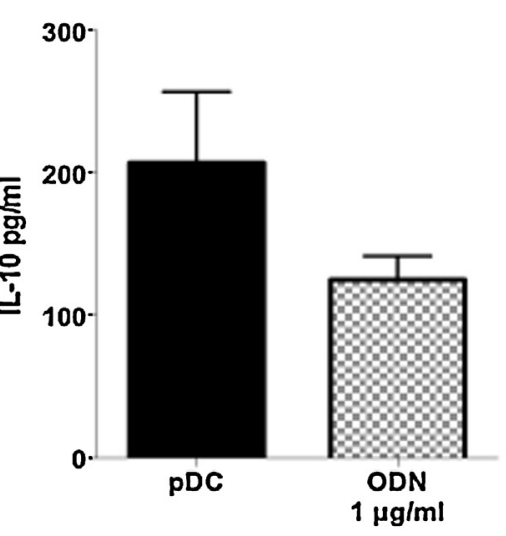
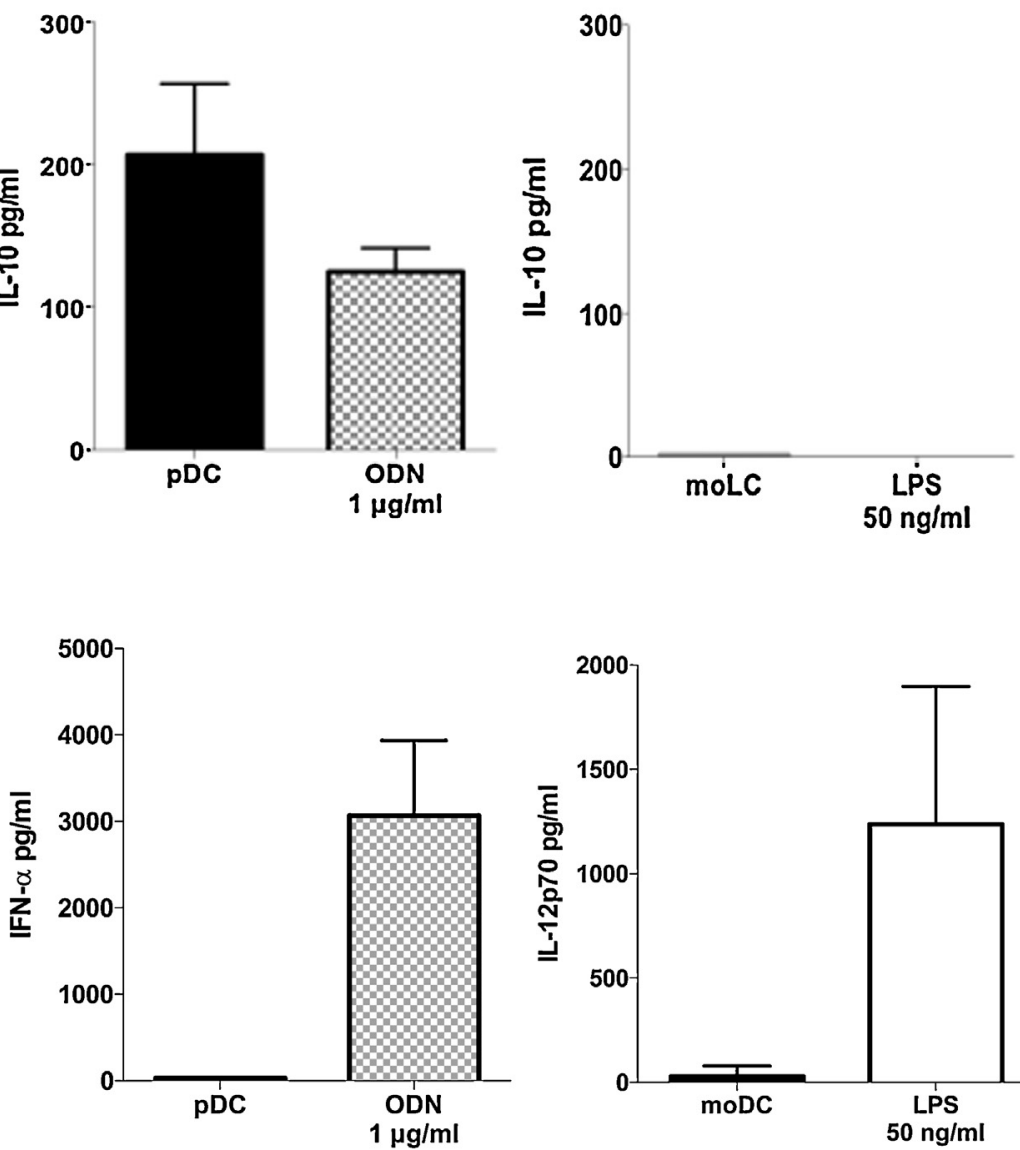

Fig. 2. Cytokine secretions of each DC subset. A. ELISA measured of IL-10 or B. IL-12p70 and IFN- $\alpha$ secretion in $48 \mathrm{~h}$ in the supernatants in un-stimulated and LPS or CPG-A ODN stimulated DCs. Bar represented the mean value $\pm \mathrm{SD}(\mathrm{pDC}$ and $\operatorname{moDCs} n=3$, moLCs $n=1$ ).

regulation of IFN- $\alpha$ secretion suggesting their potential as an attractive therapeutic target [23].

Langerhans cells are readily distinguished from other DC by the expression of a C-type lectin Langerin (CD207), associated with characteristic intra-cytoplasmic vesicles, Birbeck granules [4]. Langerhans cells form a stable self-renewing population that does not require $\mathrm{CD} 34^{+}$progenitors in the absence of inflammation [24]. It can be differentiated from monocytes [15,17], dermal resident $\mathrm{CD} 14^{+}$cells [25] and $\mathrm{CD} 1 \mathrm{c}^{+} \mathrm{DC}$ [26]. It has become clear that LCs were not only capable of triggering adaptive immune responses but also of mediating immune tolerance to self-antigens in non-inflammatory conditions [27,28]. We also demonstrated that the basal amount of IL-10 secretion was different according DC subsets, with low secretion for moDCs, higher for $\mathrm{pDCs}$ and no secretion for moLCs. This variable capacity to secrete IL-10 could be related to the intrinsic properties of each subset to become pro-tolerant DCs. The activity level of the ERK pathway stimulation is higher in moDCs than in pDCs and seems to control IL-10 secretion [29].

Large numbers of works illustrated the capacity of moDCs to become pro-tolerant at the immature and mature state as well as to induce in vitro and in vivo regulatory $\mathrm{T}$ cells [9]. Likewise, some pDCs phenotypes are able to impair $\mathrm{T}$ cell proliferation [11], activate Treg functions [21] and participate to the immune response subversion [22]. In regard to the amount of IL-10 secreted by pDCs at the basal level, these cells might have the capacity to switch $\mathrm{T}$ cell phenotype to regulatory profile, as do moDCs. Although, it remains to be demonstrated. Moreover, pDCs are sensitive to TGF- $\beta$ [30] and PRRs ligand activation leading to the inhibition of its IFN- $\alpha$ secretion [23]. Langerhans cells appear to be involved in the skin homeostasis with high sensitivity to TGF $\beta$ and to induce cross-tolerance in mice [31]. But their capacity to orientate naive T lymphocytes into regulatory phenotype remains unknown.

To conclude, we presented in this work our capacity to obtain several DC subsets and their capacity to secrete IL-10 in order to assess their potential to induce immune tolerance using PRRs stimulus.

\section{Author contributions}

NDK co-elaborated the project, designed and performed the experiments and analysed the results. AH and VC trained NDK in flow cytometry experiments. FD, LL, VC, FH and ZI were involved in manuscript reading, discussion about analysis and interpretation of the results. FVR and FD co-elaborated the project, supervised the design and the analyses of experiments. NDK and FVR wrote the article. 


\section{Disclosure of interest}

The authors declare that they have no competing interest.

\section{Acknowledgments}

FVR is supported by the EU Cost Action BM1406. This work has been funded with support from the EFS-Centre Atlantique, the French Higher Education and Research ministry under the program "ANRT" and the Labex MabImprove ANR-10LABX-53-01. Authors thank Mrs Linda Rouhault for her careful proofreading.

\section{References}

[1] Steinman RM. Dendritic cells: understanding immunogenicity. Eur J Immunol 2007;37:S53-60, http://dx.doi.org/10.1002/eji.200737400.

[2] Steinman RM. The control of immunity and tolerance by dendritic cell. Pathol Biol Paris 2003;51:59-60.

[3] Segura E, Valladeau-Guilemond J, Donnadieu M-H, Sastre-Garau X, Soumelis V, Amigorena S. Characterization of resident and migratory dendritic cells in human lymph nodes. J Exp Med 2012;209:653-60, http://dx.doi.org/10.1084/jem.20111457.

[4] Valladeau J, Ravel O, Dezutter-Dambuyant C, Moore K, Kleijmeer M, Liu Y, et al. Langerin, a novel C-type lectin specific to Langerhans cells, is an endocytic receptor that induces the formation of Birbeck granules. Immunity 2000;12:71-81.

[5] Collin M, Mcgovern N, Haniffa M. Human dendritic cell subsets. Immunology 2013;140:22-30, http://dx.doi.org/10.1111/imm.12117.

[6] Villani A-C, Satija R, Reynolds G, Sarkizova S, Shekhar K, Fletcher $\mathrm{J}$, et al. Single-cell RNA-seq reveals new types of human blood dendritic cells, monocytes and progenitors. Science 2017;356:eah4573, http://dx.doi.org/10.1126/science.aah4573.

[7] Horton C, Shanmugarajah K, Fairchild PJ. Harnessing the properties of dendritic cells in the pursuit of immunological tolerance. Biomed $\mathrm{J}$ 2017;40:80-93, http://dx.doi.org/10.1016/j.bj.2017.01.002.

[8] Amodio G, Gregori S. Human tolerogenic DC-10: perspectives for clinical applications. Transplant Res 2012;1:14, http://dx.doi.org/ 10.1186/2047-1440-1-14.

[9] Ito T, Liu Y-J, Kadowaki N. Functional diversity and plasticity of human dendritic cell subsets. Int J Hematol 2005;81:188-96, http://dx.doi.org/10.1532/IJH97.05012.

[10] Sato K, Yamashita N, Baba M, Matsuyama T. Modified myeloid dendritic cells act as regulatory dendritic cells to induce anergic and regulatory T cells. Blood 2003;101:188-3581, http://dx.doi.org/10.1182/ blood-2002-09-2712.

[11] Ferreira GB. Vitamin D3 induces tolerance in human dendritic cells by activation of intracellular metabolic pathways. Cell Rep 2015;10:711-25, http://dx.doi.org/10.1016/j.celrep.2015.01.013.

[12] Arbez J, Lamarthée B, Gaugler B, Saas P. Histone deacetylase inhibitor valproic acid affects plasmacytoid dendritic cells phenotype and function. Immunobiology 2014;219:637-43, http://dx.doi.org/ 10.1016/j.imbio.2014.03.013.

[13] Lagaraine C, Hoarau C, Chabot V, Velge-roussel F, Lebranchu Y. Human mycophenolic acid treated dendritic cells have immature co-stimulary abilities but mature migratory phenotype. J Leukoc Biol 2005;17:351-63.

[14] Ciancio G, Sageshima J, Chen L, Gaynor JJ, Hanson L, Tueros L, et al. Advantage of rapamycin over mycophenolate mofetil when used with tacrolimus for simultaneous pancreas kidney transplants: randomized, single-center trial at 10 years. Am J Transplant 2012;12:3363-76, http://dx.doi.org/10.1111/j.1600-6143.2012.04235.x.

[15] Picarda G, Chéneau C, Humbert J-M, Bériou G, Pilet P, Martin J, et al. Functional Langerin ${ }^{\text {high }}$ - expressing langerhans-like cells can arise from CD1 high $\mathrm{CD} 16^{-}$human blood monocytes in serum-free condition. J Immunol 2016;196:3716-28, http://dx.doi.org/10.4049/jimmunol.1501304.

[16] Caux C, Ait-Yahia S, Chemin K, de Bouteiller O, Dieu-Nosjean MC, Homey B, et al. 17-Dendritic cell biology and regulation of dendritic cell trafficking by chemokines. Springer Semin Immunopathol 2000;22:345-69.

[17] Palucka AK, Ueno H, Fay JW, Banchereau J. Taming cancer by inducing immunity via dendritic cells. Immunol Rev 2007;220:129-50, http://dx.doi.org/10.1111/j.1600-065X.2007.00575.x.

[18] Xia MJ, Shan J, Li YP, Zhou YN, Guo YJ, Sun GX, et al. Adoptive transfusion of tolerant dendritic cells prolong the survival of renal allografts: a systematic review. J Evid-Based Med 2013;6:250-64, http://dx.doi.org/10.1111/jebm.12070.

[19] Duraes FV, Lippens C, Steinbach K, Dubrot J, Brighouse D, BendrissVermare $\mathrm{N}$, et al. pDC therapy induces recovery from EAE by recruiting endogenous $\mathrm{pDC}$ to sites of CNS inflammation. J Autoimmun 2016;67:8-18, http://dx.doi.org/10.1016/j.jaut.2015.08.014.

[20] Dzionek a, Sohma Y, Nagafune J, Cella M, Colonna M, Facchetti F, et al. BDCA-2, a novel plasmacytoid dendritic cell-specific type II C-type lectin, mediates antigen capture and is a potent inhibitor of interferon alpha/beta induction. J Exp Med 2001;194:1823-34, http://dx.doi.org/10.1084/jem.194.12.1823.

[21] Guéry L, Hugues S. Tolerogenic and activatory plasmacytoid dendritic cells in autoimmunity. Front Immunol 2013;4:59, http://dx.doi.org/ 10.3389/fimmu.2013.00059.

[22] Crow MK. Type I interferon in the pathogenesis of lupus. J Immunol Baltim Md 1950 2014;192:5459-68, http://dx.doi.org/ 10.4049/jimmunol.1002795.

[23] Chappell CP, Giltiay NV, Draves KE, Chen C, Hayden-Ledbetter MS, Shlomchik MJ, et al. Targeting antigens through blood dendritic cell antigen 2 on plasmacytoid dendritic cells promotes immunologic tolerance. J Immunol 2014;192:5789-801, http://dx.doi.org/ 10.4049/jimmunol.1303259.

[24] Chopin M, Seillet C, Chevrier S, Wu L, Wang H, Morse HC, et al. Langerhans cells are generated by two distinct PU.1dependent transcriptional networks. J Exp Med 2013;210:2967-80, http://dx.doi.org/10.1084/jem.20130930.

[25] Larregina AT, Morelli AE, Spencer LA, Logar AJ, Watkins SC, Thomson AW, et al. Dermal-resident CD14+ cells differentiate into Langerhans cells. Nat Immunol 2001;2:1151-8, http://dx.doi.org/10.1038/ni731.

[26] Martínez-Cingolani C, Grandclaudon M, Jeanmougin M, Jouve M, Zollinger R, Soumelis V. Human blood BDCA-1 dendritic cells differentiate into Langerhans-like cells with thymic stromal lymphopoietin and TGF- $\beta$. Blood 2014;124:2411-20, http://dx.doi.org/ 10.1182/blood-2014-04-568311.

[27] Klechevsky E, Morita R, Liu M, Cao Y, Coquery S, Thompson-Snipes $\mathrm{L}$, et al. Functional specializations of human epidermal Langerhans cells and CD14+ dermal dendritic cells. Immunity 2008;29:497-510, http://dx.doi.org/10.1016/j.immuni.2008.07.013.

[28] Seneschal J, Clark RA, Gehad A, Baecher-Allan CM, Kupper TS. Human epidermal Langerhans cells maintain immune homeostasis in skin by activating skin resident regulatory $\mathrm{T}$ cells. Immunity 2012;36:873-84, http://dx.doi.org/10.1016/j.immuni.2012.03.018.

[29] Kaiser F, Cook D, Papoutsopoulou S, Rajsbaum R, Wu X, Yang H-T, et al. TPL- 2 negatively regulates interferon- $\beta$ production in macrophages and myeloid dendritic cells. J Exp Med 2009;206:1863-71, http://dx.doi.org/10.1084/jem.20091059.

[30] Bonnefoy F, Couturier M, Clauzon A, Remy-Martin J-P, Gaugler B, Tiberghien P, et al. TGF- -exposed plasmacytoid dendritic cells participate in Th17 commitment. J Immunol 2011;186:6157-64, http://dx.doi.org/10.4049/jimmunol.1002497.

[31] Flacher V, Tripp CH, Mairhofer DG, Steinman RM, Stoitzner P, Idoyaga $J$, et al. Murine Langerin+ dermal dendritic cells prime CD8+ T cells while Langerhans cells induce cross-tolerance. EMBO Mol Med 2014;6:1191-204, http://dx.doi.org/10.15252/emmm.201303283. 